Australian Journal of

Crop Science

AJCS 14(02):319-324 (2020)

doi: $10.21475 /$ ajcs.20.14.02.p2320

AJCS

ISSN:1835-2707

\title{
Water status, cell damage and gas exchanges in West Indian cherry (Malpighia emarginata) under salt stress and nitrogen fertilization
}

\author{
Geovani Soares de Lima ${ }^{1}$, Francisco Wesley Alves Pinheiro ${ }^{2}$, Adaan Sudário Dias ${ }^{2}$, Hans Raj Gheyi ${ }^{3}$, Saulo \\ Soares da Silva ${ }^{2}$, Lauriane Almeida dos Anjos Soares ${ }^{1}$, André Alisson Rodrigues da Silva ${ }^{2}$, Pedro Dantas \\ Fernandes ${ }^{2}$, Jussara Silva Dantas ${ }^{1}$
}

${ }^{1}$ Federal University of Campina Grande, Academic Unit of Agrarian Sciences, Pombal, 58.840-000, Paraíba, Brazil

${ }^{2}$ Federal University of Campina Grande, Academic Unit of Agricultural Engineering, Campina Grande, 58.109-970,

Paraíba, Brazil

${ }^{3}$ Federal University of Recôncavo of Bahia, Nucleus of Soil and Water Engineering, Cruz das Almas, 44.380-000, Bahia, Brazil

*Corresponding author: geovanisoareslima@gmail.com

\begin{abstract}
This study was conducted to evaluate water status, cell damage and gas exchanges of West Indian cherry grown under saline water irrigation and nitrogen $(\mathrm{N})$ fertilization in the post-grafting stage. The experiment was carried out in drainage lysimeters under greenhouse conditions in Regolithic Neosol with sandy loam texture. Treatments consisted of two levels of electrical conductivity of water (ECW) (0.8 and $4.5 \mathrm{dS} \mathrm{m}^{-1}$ ) and four $\mathrm{N}$ doses (70; 85; 100 and $115 \%$ of the $\mathrm{N}$ recommendation), arranged in randomized blocks, with three replicates. The dose relative to $100 \%$ corresponded to $200 \mathrm{~g}$ of $\mathrm{N}$ per plant per year. Irrigation with $4.5 \mathrm{dS} \mathrm{m}^{-1}$ electrical conductivity water resulted in a reduction in stomatal conductance, transpiration, $\mathrm{CO}_{2}$ assimilation rate and instantaneous carboxylation efficiency but increased cell damage percentage and internal $\mathrm{CO}_{2}$ concentration in West Indian cherry plants. Inhibition of $\mathrm{CO}_{2}$ assimilation rate in West Indian cherry plants is related to non-stomatal effects. Irrigation with $4.5 \mathrm{dS} \mathrm{m}^{-1}$ water and fertilization with $115 \%$ of $\mathrm{N}$ recommendation intensified leaf water saturation deficit in the West Indian cherry crop. The BRS Jaburu West Indian cherry was sensitive to $4.5 \mathrm{dS} \mathrm{m}^{-1}$ water salinity.
\end{abstract}

Keywords: Malpighia emarginata, salinity, nitrogen.

Abbreviations: gs_stomatal conductance; $E_{-}$transpiration; $A_{-} \mathrm{CO}_{2}$ assimilation rate, $\mathrm{Ci}$ internal $\mathrm{CO}_{2}$ concentration; ElCl_instantaneous carboxylation efficiency; WUE_instantaneous water use efficiency; ECw_electrical conductivity of the irrigation water; water saturation deficit_WSD, percentage of cell membrane damage _\%D),

Introduction

Belonging to the Malpighiaceae family, West Indian cherry (Malpighia emarginata) is a fruit crop cultivated in Brazil, especially in the semi-arid region of the Northeast, due to the versatility of its production, standing out for its high content of ascorbic acid. In addition, it contains important bioactive compounds, such as anthocyanins, carotenoids, phenolic compounds, natural dyes, compounds with known action in the prevention of degenerative diseases, biological activity and health maintenance (Dembitsky et al., 2011). It has become an important option to diversify the economy for both enabling farmworkers to work, where they live and generating jobs for fruit growers.

Although the semi-arid region of Northeast Brazil has favorable edaphoclimatic conditions for West Indian cherry cultivation, the rainfall scarcity combined with high evaporative demand lead to water deficit during most of the year, which makes irrigation an essential practice to guarantee the agricultural production (Oliveira et al., 2010). Thus, an alternative to increase water availability to crops can be the use of saline waters and the electrical conductivity values commonly found in the region with higher than $1.5 \mathrm{dS} \mathrm{m}^{-1}$ (Neves et al., 2010). Excess of salts in the water reduces the osmotic potential of the soil solution, affecting water availability and causing toxicity by specific ions, nutritional imbalance and other damages related to indirect effects through physical and chemical changes in the soil (Neves et al., 2009).

In addition, presence of excessive salts in the root zone can negatively affect cell membrane integrity (Silva et al., 2010) and cause reduction in the photosynthetic capacity, leading to reduction in transpiration and increase in cell mechanical 
resistance. It will happen due to the mechanism of stomatal closure, decreasing water losses by transpiration and $\mathrm{CO}_{2}$ supply to the leaves (Amorim et al., 2010). Nonetheless, crop sensitivity to salt stress depends on other factors such as species, cultivar, types of salts, stress intensity and duration, crop and irrigation managements, edaphoclimatic conditions and fertilization (Deuner et al., 2011).

However, the deleterious effects caused by salinity on crops have been overcome due to the adoption of adequate fertilization management practices. In this context, mineral nutrition stands out among the main strategies employed to increase crop yield and profitability. Nitrogen $(\mathrm{N})$ is one of the main macronutrients responsible for such increase (Chaves et al., 2011) due to the functions of this element in plant metabolism. It performs structural function, participating in the synthesis of amino acids, proteins, coenzymes, nucleic acids, vitamins and chlorophyll, which are among the organic compounds essential to plant survival (Cantarella, 2007).

Given its importance as constituent of various compounds, $\mathrm{N}$ is involved in several biochemical reactions, which are necessary for plant metabolism, standing out as activator of various enzymatic systems, many of which participate in the processes of photosynthesis and respiration, resulting in stimulus to growth (Epstein and Bloom, 2006). In this context, various studies have found that the accumulation of these organic solutes increased the osmotic adjustment capacity of plants to salinity (Silva et al., 2008; Barhoumi et al., 2010).

Based on this premise, this study aimed to evaluate the water status, cell damage and gas exchanges in West Indian cherry irrigated with saline water and $\mathrm{N}$ fertilization, in the postgrafting stage.

\section{Results and discussion}

\section{Effect of saline stress and nitrogen doses on water status and cell damage in West Indian cherry}

According to the summary analysis of variance (Table 1), water salinity levels had significant influence on water saturation deficit (WSD), percentage of cell membrane damage (\%D), stomatal conductance $(g s)$, internal $\mathrm{CO}_{2}$ concentration $(\mathrm{Ci})$, leaf transpiration $(E), \mathrm{CO}_{2}$ assimilation rate $(A)$ and instantaneous carboxylation efficiency (EICi) in the West Indian cherry plants. Nitrogen doses (ND) did not cause significant difference in any of the variables analysed. However, the interaction between factors (SL x ND) significantly affected leaf water saturation deficit in West Indian cherry plants during the fruiting stage. Leaf water saturation deficit was significantly affected by the interaction between factors ( $S L \times N D$ ). According to the regression equations (Fig $1 \mathrm{~A}$ ), the data of plants subjected to irrigation with low-salinity water $\left(0.8 \mathrm{dS} \mathrm{m}^{-1}\right)$ fitted to a quadratic model, whose minimum estimated value (15.15\%) was obtained in West Indian cherry plants, which received the highest $\mathrm{N}$ dose. As $\mathrm{N}$ dose was increased, there was an accentuated reduction in WSD. However, the highest leaf water saturation deficit was occurred when West Indian cherry plants were subjected to the highest ECW level $\left(4.5 \mathrm{dSm}^{-1}\right)$. The increase was $8.81 \%$ for every $15 \%$ increase in $\mathrm{N}$ dose. The regression equations (Fig $1 \mathrm{~A}$ ) show that with $4.5 \mathrm{dS} \mathrm{m}^{-1}$ water and dose of $115 \%$ of $\mathrm{N}$ recommendation, the WSD was increased by $3.83 \%$, compared with plants subjected to ECW of $0.8 \mathrm{dS} \mathrm{m}^{-1}$. Increments of leaf water saturation deficit in West Indian cherry can be attributed to the high salt concentration in the irrigation water $\left(E C W=4.5 \mathrm{dS} \mathrm{m}^{-1}\right)$. The increasing $\mathrm{N}$ doses is associated with changes in the concentration of cell sap (Fig 1B), resulting from the reduction in the osmotic potential of the soil solution, which contributed to the decrease in leaf water potential. It negatively influences the water status needed to maintain physiological processes that are essential to plant survival (Benzarti et al., 2014).

According to the means comparison test for the percentage of cell membrane damage (\%D) (Fig 1B), plants irrigated with lowsalinity water $\left(0.8 \mathrm{dS} \mathrm{m}^{-1}\right)$ significantly differed from those subjected to ECW of $4.5 \mathrm{dS} \mathrm{m}^{-1}$. Comparing the means between treatments, it is noted that plants irrigated with lowest water salinity level had the lowest \%D in the leaf tissue (10.66\%), evidencing that cell membrane integrity was maintained in the West Indian cherry leaf tissues. Conversely, plants under highsalinity water showed the highest \%D (14.08\%). Thus, it is evident that high concentrations of salts caused disorganization in cell membrane, leading to reduction in homeostasis, a situation that reflects the extension of the lipid peroxidation caused by reactive oxygen species (ROS). The superoxide radical $\left(\bullet \mathrm{O}^{2-}\right)$, besides other highly reactive chemical species such as singlet oxygen $\left({ }^{1} \mathrm{O}_{2}\right)$, the hydroxyl radical $\left({ }^{\circ} \mathrm{OH}^{-}\right)$and hydrogen peroxide $\left(\mathrm{H}_{2} \mathrm{O}_{2}\right)$ can initiate lipid peroxidation (Mendes et al., 2011). Evaluating the behavior of three citrus scion/rootstock combinations under greenhouse conditions and different levels of irrigation water salinity $(0.6$ to $3.0 \mathrm{dS} \mathrm{m}^{-1}$ ), Sousa et al. (2017) also found that irrigation with water salinity leads to increment in the damage to cell membrane.

\section{Effect of saline stress and nitrogen doses on gas exchanges in West Indian cherry}

Stomatal conductance in West Indian cherry was significantly affected by the irrigation with different salinity levels and, according to the means comparison test (Fig $1 \mathrm{C}$ ), in plants subjected to the highest ECW level $\left(4.5 \mathrm{dS} \mathrm{m}^{-1}\right)$, gs decreased

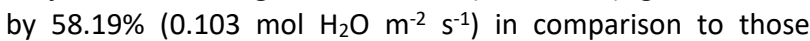
irrigated with the lowest salinity level $\left(0.8 \mathrm{dS} \mathrm{\textrm {m } ^ { - 1 }}\right)$. The stomatal closure observed in plants irrigated with high-salinity water (Fig 1C) possibly occurred due to the osmotic effect of the dissolved salts. This situation has deleterious effect on the gas exchanges due to reduction in osmotic potential of the solution, which limits the water flux from the soil to plants. Consequently, it reduces leaf water potential, characterizing the water stress (Lima et al., 2015). However, reduction in stomatal opening can be considered as a strategy to decrease water losses to the atmosphere and, consequently, maintain high turgor of guard cells, directly affecting the formation of carbohydrates in the photosynthesis and the production. Sá et al. (2017), evaluated the effects of saline water irrigation (ECW from 0.6 to $3.8 \mathrm{dS} \mathrm{m}^{-1}$ ) on the same cultivar (BRS 366 Jaburu), 
Table 1. Summary of analysis of variance for leaf water saturation deficit (WSD), percentage of cell membrane damage (\%D), stomatal conductance $(g s)$, internal $\mathrm{CO}_{2}$ concentration $(C i)$, leaf transpiration $(E), \mathrm{CO}_{2}$ assimilation rate $(A)$, instantaneous water use efficiency (WUEi) and instantaneous carboxylation efficiency (EICi) in West Indian cherry plants grown under different levels of water salinity and nitrogen doses, during the fruiting stage, in the second year of cultivation.

\begin{tabular}{|c|c|c|c|c|c|c|c|c|c|}
\hline \multirow{2}{*}{ Source of variation } & \multirow{2}{*}{ DF } & \multicolumn{8}{|c|}{ Mean squares } \\
\hline & & WSD & $\% \mathrm{D}$ & gs & $\mathrm{Ci}$ & $E$ & $A$ & WUEi & $E I C i$ \\
\hline Saline levels (SL) & 1 & $267.60^{* *}$ & $70.21^{* *}$ & $0.0640^{* *}$ & $30459.37^{*}$ & $0.47^{*}$ & $28.66^{* *}$ & $7.98^{\mathrm{ns}}$ & $0.0010^{*}$ \\
\hline $\mathrm{N}$ doses (ND) & 3 & $17.81^{\mathrm{ns}}$ & $1.21^{\mathrm{ns}}$ & $0.0009^{n s}$ & $457.37^{\text {ns }}$ & $0.07^{\text {ns }}$ & $1.33^{\text {ns }}$ & $3.21^{\mathrm{ns}}$ & $0.00004^{\text {ns }}$ \\
\hline Linear regression & 1 & $10.93^{\text {ns }}$ & $2.94^{\mathrm{ns}}$ & $0.0014^{\mathrm{ns}}$ & $357.07^{\text {ns }}$ & $0.001^{\mathrm{ns}}$ & $0.60^{\text {ns }}$ & $5.06^{\mathrm{ns}}$ & $0.000001^{\mathrm{ns}}$ \\
\hline Quadratic regression & 1 & $6.44^{\text {ns }}$ & $0.33^{\text {ns }}$ & $0.0013^{\text {ns }}$ & $0.04^{\mathrm{ns}}$ & $0.16^{\text {ns }}$ & $0.05^{\text {ns }}$ & $3.65^{\mathrm{ns}}$ & $0.000001^{\mathrm{ns}}$ \\
\hline Interaction (SL x ND) & 3 & $721.48^{* *}$ & $7.64^{\text {ns }}$ & $0.0032^{\mathrm{ns}}$ & $1150.81^{\mathrm{ns}}$ & $0,05^{\text {ns }}$ & $2.05^{\mathrm{ns}}$ & $4.47^{\mathrm{ns}}$ & $0.00002^{\mathrm{ns}}$ \\
\hline Blocks & 2 & $16.29^{\text {ns }}$ & $0.11^{\mathrm{ns}}$ & $0.0048^{\text {ns }}$ & $8631.54^{\text {ns }}$ & $0.21^{\text {ns }}$ & $0.20^{\text {ns }}$ & $1.99^{\text {ns }}$ & $0.00004^{\text {ns }}$ \\
\hline Residual & 14 & 282.01 & 2.68 & 0.0025 & 1879.20 & 0.07 & 1.23 & 3.96 & 0.00005 \\
\hline CV (\%) & & 17.62 & 13.25 & 10.25 & 14.97 & 15.29 & 24.23 & 17.79 & 13.41 \\
\hline
\end{tabular}

$\mathrm{ns}, * *, *$ respectively, not significant, significant at $\mathrm{p}<0.01$ and $\mathrm{p}<0.05$.
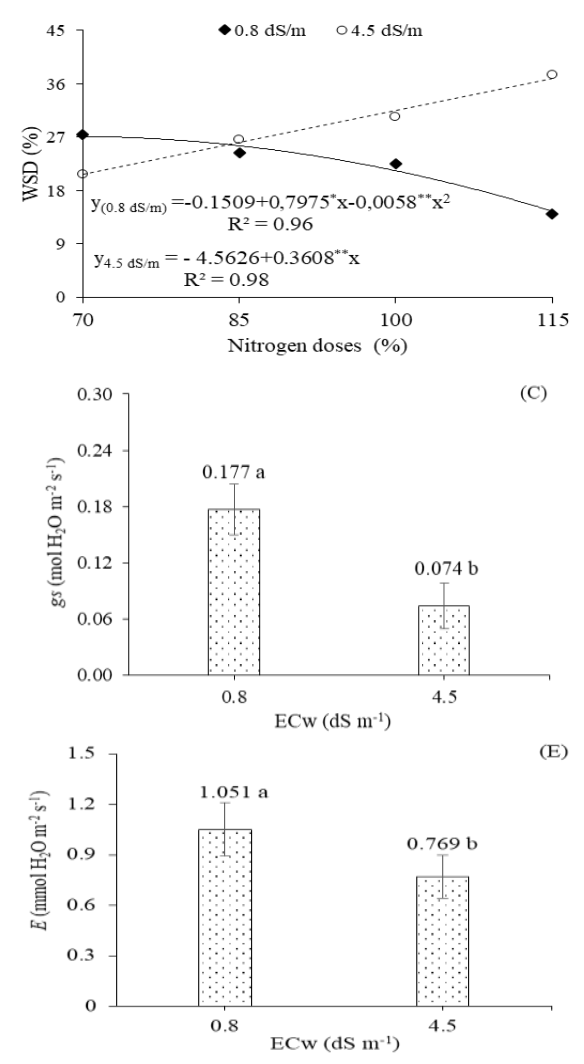

(A)
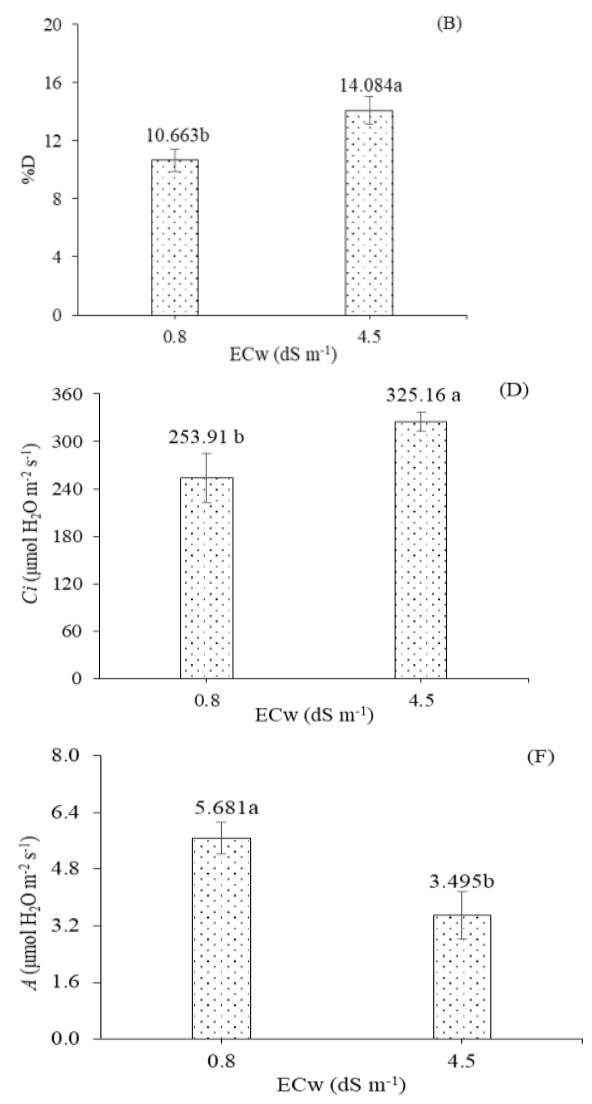

(G)

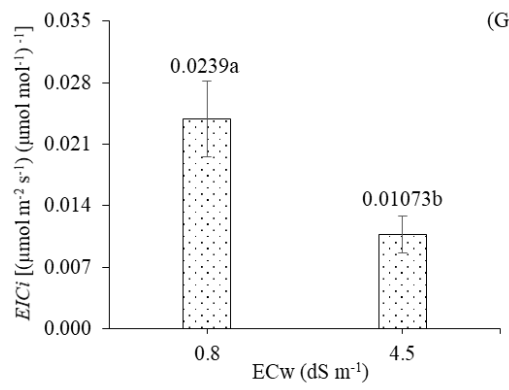

Fig 1. Leaf water saturation deficit - WSD (A) as a function of the interaction between levels of irrigation water salinity - ECw and nitrogen doses, and

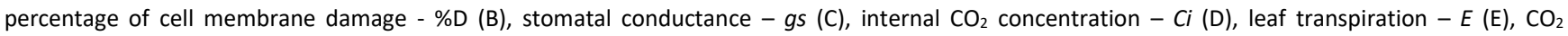
assimilation rate $-A(F)$ and instantaneous carboxylation efficiency - EICi (G) in West Indian cherry plants irrigated using solutions with different ECW levels, during the fruiting stage. Bars represent the standard error of the mean $(n=3)$. Mean with different letter indicates that treatments differ by Tukey test, $\mathrm{p}<0.05$. 
Table 2. Physical and chemical characteristics of the soil used in the experiment.

\begin{tabular}{|c|c|c|c|c|c|c|c|c|}
\hline \multicolumn{9}{|c|}{ Chemical characteristics } \\
\hline \multirow{2}{*}{$\begin{array}{l}\mathrm{pH}\left(\mathrm{H}_{2} \mathrm{O}\right) \\
(1: 2.5)\end{array}$} & \multirow{2}{*}{$\begin{array}{l}\text { OM } \\
\mathrm{g} \mathrm{kg}^{-1}\end{array}$} & \multirow{2}{*}{$\begin{array}{l}\mathrm{P} \\
\mathrm{mg} \mathrm{kg}^{-1}\end{array}$} & $\mathrm{~K}^{+}$ & $\mathrm{Na}^{+}$ & $\mathrm{Ca}^{2+}$ & $\mathrm{Mg}^{2+}$ & $\mathrm{Al}^{3+}$ & $\mathrm{H}^{+}$ \\
\hline & & & \multicolumn{6}{|c|}{ 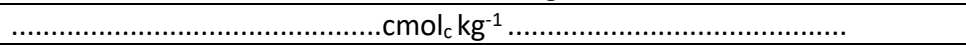 } \\
\hline 5.58 & 2.93 & 39.2 & 0.23 & 1.64 & 9.07 & 2.78 & 0.00 & 8.61 \\
\hline \multicolumn{4}{|c|}{.......... Chemical characteristics............. } & \multicolumn{5}{|c|}{ 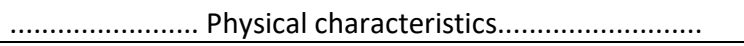 } \\
\hline \multirow{2}{*}{$\begin{array}{l}\text { CEC } \\
\mathrm{cmol}_{\mathrm{c}} \mathrm{kg}^{-1}\end{array}$} & \multirow{2}{*}{$\begin{array}{l}\text { ESP } \\
(\%)\end{array}$} & \multirow{2}{*}{$\begin{array}{l}\text { ECse } \\
\mathrm{dS} \mathrm{m}^{-1}\end{array}$} & \multirow{2}{*}{$\begin{array}{l}\text { SAR } \\
\left(\mathrm{mmol} \mathrm{L}^{-1}\right)^{0.5}\end{array}$} & \multicolumn{3}{|c|}{ Size fraction $\left(\mathrm{g} \mathrm{kg}^{-1}\right)$} & \multicolumn{2}{|c|}{ Water content - dag $\mathrm{kg}^{-1}$} \\
\hline & & & & Sand & Silt & Clay & $33.42 \mathrm{kPa}^{1}$ & $1519.5 \mathrm{kPa}$ \\
\hline 22.33 & 7.34 & 2.15 & 0.67 & 572.7 & 100.7 & 326.6 & 25.91 & 12.96 \\
\hline
\end{tabular}

also found reduction in $g s$, which was equal to $14 \%$ per unit increase in irrigation water salinity.

Unlike the trend observed for stomatal conductance, the internal $\mathrm{CO}_{2}$ concentration of West Indian cherry plants irrigated with $4.5 \mathrm{dS} \mathrm{m}^{-1}$ water was statistically higher than that of plants subjected to ECW of $0.8 \mathrm{dS} \mathrm{m}^{-1}$ (Fig 1D). There was an increase of $71.25 \mu \mathrm{mol} \mathrm{H} \mathrm{H}_{2} \mathrm{~m}^{-2} \mathrm{~s}^{-1}$ in the $\mathrm{Ci}$ of plants subjected to irrigation with $\mathrm{ECW}$ of $4.5 \mathrm{dS} \mathrm{m}^{-1}$ compared with those subjected to $0.8 \mathrm{dS} \mathrm{m}^{-1}$. Based on the data of internal $\mathrm{CO}_{2}$ concentration (Fig 1D), it becomes evident that its lower value observed in plants subjected to $E C W$ of $0.8 \mathrm{dSm}^{-1}$ is associated with the higher $\mathrm{CO}_{2}$ assimilation rate (Fig $1 \mathrm{~F}$ ). However, the increase in internal $\mathrm{CO}_{2}$ concentration in plants cultivated under high salinity $\left(4.5 \mathrm{dS} \mathrm{m}^{-1}\right)$ suggests that the carbon entering the leaf mesophyll cell was not being metabolized by the photosynthetic apparatus due to the low activity of the enzyme ribulose-1,5-bisphosphate carboxylase/oxygenase (RuBisCO), as reported by Habermann et al. (2003). In addition, such increase in internal $\mathrm{CO}_{2}$ concentration is an indication that there was no restriction in $\mathrm{CO}_{2}$ acquisition by the crop. However, when it reached the mesophyll cells, the fixation process during the carboxylation phase was compromised (Freire et al., 2014), which can be related to the degradation of the photosynthetic apparatus in response to the senescence of leaf tissues, resulting from the stress caused by the excess of salts (Silva et al., 2013).

Leaf transpiration $(E)$ also significantly differed as a function of the different salinity levels (Fig $1 \mathrm{E}$ ), and its highest value (1.05 $\mathrm{mmol} \mathrm{H}_{2} \mathrm{Om}^{-2} \mathrm{~s}^{-1}$ ) was obtained when low-salinity water (0.8 dS $\mathrm{m}^{-1}$ ) was used in irrigation. Nonetheless, West Indian cherry plants irrigated using water with ECW of $4.5 \mathrm{dS} \mathrm{m}^{-1}$ showed $E$ of $0.76 \mathrm{mmol} \mathrm{H}_{2} \mathrm{O} \mathrm{m}^{-2} \mathrm{~s}^{-1}$, i.e., reduction of $26.83 \%$ in comparison to those subjected to $\mathrm{ECW}$ of $0.8 \mathrm{dS} \mathrm{m}^{-1}$. Thus, the partial closure of the stomata (Fig $1 \mathrm{C}$ ) associated with the osmotic effects of salinity led to reduction in leaf transpiration (Fig 1E). This may have affected the capacity of water absorption by the root system as a strategy of this species to tolerate the salt stress, aiming to reduce the absorption of toxic ions dissolved, especially $\mathrm{Na}^{+}$and $\mathrm{Cl}^{-}$, decreasing the toxicity by specific ions (Syvertsen and Garcia-Sanchez, 2014).

Carbon dioxide assimilation rate $(A)$ is directly influenced by stomatal conductance and based on the means comparison test (Fig 1F), West Indian cherry plants subjected to ECW of 0.8 $\mathrm{dSm}^{-1}$ were statistically different from those irrigated with 4.5
$\mathrm{dS} \mathrm{m}^{-1}$ water. There was a reduction of $38.48 \%$ in $A(2.18 \mu \mathrm{mol}$ $\mathrm{H}_{2} \mathrm{O} \mathrm{m}^{-2} \mathrm{~s}^{-1}$ ) between plants subjected to the highest ( $4.5 \mathrm{dS} \mathrm{m}^{-}$ $\left.{ }^{1}\right)$ and lowest $\left(0.8 \mathrm{dS} \mathrm{m}^{-1}\right)$ salinity levels. The reduction in $\mathrm{CO}_{2}$ assimilation rate in plants irrigated with high-salinity water can be attributed to the stomatal closure. This evidenced in the present study by the stomatal conductance (Fig 1C), by which the consequent reduction in the normal $\mathrm{CO}_{2}$ flux towards the carboxylation site was one of the main factors responsible for the reduction in photosynthesis (Bosco et al., 2009). In addition, the reduction in cell turgor associated with the toxic effects, particularly of $\mathrm{Na}^{+}$and $\mathrm{Cl}^{-}$, also contributed to the reduction in $A$. Likewise, Sousa et al. (2016), in a study evaluating gas exchanges of citrus (scion/rootstock combinations) as a function of irrigation water salinity ( $E C W$ from 0.6 to $3.0 \mathrm{dS} \mathrm{m}^{-1}$ ), also observed reduction in $\mathrm{CO}_{2}$ assimilation rate, equal to $20.33 \%$ per unit increase in $\mathrm{ECw}$.

According to the means comparison test (Fig 1G), the instantaneous carboxylation efficiency (EICi) was significantly reduced in West Indian cherry plants irrigated with the highest ECW level ( $\left.4.5 \mathrm{dS} \mathrm{m}^{-1}\right)$, compared with those subjected to 0.8

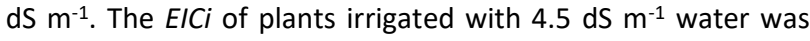
decreased by $55.10 \%$ [0.0131 $\left.\left(\mu \mathrm{mol} \mathrm{m}^{-2} \mathrm{~s}^{-1}\right)\left(\mu \mathrm{mol} \mathrm{mol}^{-1}\right){ }^{-1}\right]$, compared to plants under the lowest salinity level $\left(0.8 \mathrm{dS} \mathrm{m}^{-1}\right)$. The expressive reduction in the $\mathrm{EICi}$ of West Indian cherry plants subjected to $4.5 \mathrm{dS} \mathrm{m}^{-1}$ could be resulted from the low $\mathrm{CO}_{2}$ assimilation rate (Fig $1 \mathrm{~F}$ ), which is attributed to the $\mathrm{CO}_{2}$ found in the substomatal chamber (Fig 1C). It is evident that if the internal $\mathrm{CO}_{2}$ concentration increases, a reduction in $\mathrm{CO}_{2}$ consumption in the chloroplasts may occur due to reduction in photosynthesis. The EICi ratio will also decrease. Lúcio et al. (2013) added that the osmotic and toxic effects of excess salts associated with stomatal and non-stomatal causes are also responsible for the reduction in the EICi ratio.

\section{Materials and methods}

Localization, experimental procedure, treatments and plant material

The experiment was carried out in pots equipped with drainage lysimeters under greenhouse conditions, at the Center of Technology and Natural Resources of the Federal University of Campina Grande (CTRN/UFCG), located in the municipality of Campina Grande, PB, Brazil, at the local 
geographic coordinates $7^{\circ} 15^{\prime} 18^{\prime \prime} \mathrm{S}$ and $35^{\circ} 52^{\prime} 28^{\prime \prime} \mathrm{W}$, at 550 $m$ of altitude.

The experimental design was randomized blocks with three replicates in a $2 \times 4$ factorial arrangement. The treatments consisted of two levels of electrical conductivity of the irrigation water - ECW $\left(0.8\right.$ and $\left.4.5 \mathrm{dS} \mathrm{m}^{-1}\right)$ and four $\mathrm{N}$ doses [70; $85 ; 100$ and $115 \%$ of the dose recommended by Cavalcante et al. (2008)]. The dose relative to $100 \%$ corresponded to $200 \mathrm{~g}$ of $\mathrm{N}$ per plant per year.

Irrigation solutions with the respective $\mathrm{ECW}$ levels were prepared by dissolving the salts $\mathrm{NaCl}, \mathrm{CaCl}_{2} \cdot 2 \mathrm{H}_{2} \mathrm{O}$ and $\mathrm{MgCl}_{2} .6 \mathrm{H}_{2} \mathrm{O}$, at equivalent proportion of $7: 2: 1$, respectively, in water ( $E C W=0.6 \mathrm{dS} \mathrm{m}^{-1}$ ) from the public supply system of Campina Grande, PB, based on the relationship between ECW and the concentration of salts $\left(10^{*} \mathrm{mmol}_{\mathrm{c}} \mathrm{L}^{-1}=\mathrm{ECW} \mathrm{dS} \mathrm{m} \mathrm{m}^{-1}\right)$, according to Richards (1954).

\section{Establishment and management of the experiment}

The lysimeters were filled with a 1-kg layer of crushed stone $\mathrm{n}$ 0 , followed by $250 \mathrm{~kg}$ of eutrophic Regolithic Neosol with sandy loam texture, properly pounded to break up clods, from the rural area of the municipality of Esperança, PB. Its chemical and physical characteristics (Table 2) were obtained according to the methodologies proposed by Donagema et al. (2011).

A 4-mm-diameter drain was installed at the bottom of each lysimeter to collect drained water for evaluation and to determine plant water consumption. The tip of the drain inside the pot was wrapped with a nonwoven geotextile (Bidim OP 30) to avoid clogging by soil material.

The rootstocks used in the experiment were 'Crioula' West Indian cherry seedlings from EMBRAPA Tropical Agroindustry, located in Pacajus-CE. At transplantation, the seedlings were 240 days old. During the acclimation period in the greenhouse, West Indian cherry plants were irrigated with low-salinity water $\left(0.8 \mathrm{dS} \mathrm{m}^{-1}\right)$. BRS 366 Jaburu was used as scion variety. This cultivar stands out for its high yield $\left(57 \mathrm{t} \mathrm{ha}^{-1}\right)$, which

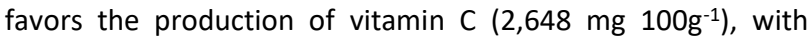
height of about $1.87 \mathrm{~cm}$ and crown diameter of $2.18 \mathrm{~m}$. Its fruits are shiny, with mean weights of 4 to $5 \mathrm{~g}$ when unripe, adequate to obtain vitamin $\mathrm{C}$, and 6 to $7 \mathrm{~g}$ after ripening (EMBRAPA, 2012).

Before transplanting the seedlings, the soil was brought to field capacity using the solutions of the respective treatments. After transplanting, irrigation was daily performed, by applying a water volume to maintain soil moisture close to field capacity. The volume was applied according to the crop water requirement, estimated by water balance: volume applied minus volume drained in the previous irrigation, plus a leaching fraction of 0.10 .

Fertilization with potassium and phosphorus were carried out as recommended by Cavalcante (2008), by applying equivalent to 333.3 and $230.7 \mathrm{~g}$ per plant, respectively, of potassium chloride and monoammonium phosphate. Nitrogen and potassium were split into 12 equal parts, applied monthly. Phosphorus was supplied in 3 equal applications, at 20-day intervals. To meet probable deficiencies of micronutrients, plants were weekly sprayed with a solution of Ubyfol containing $1.5 \mathrm{~g} \mathrm{~L}^{-1}\left[\left(\mathrm{~N}(15 \%) ; \mathrm{P}_{2} \mathrm{O}_{5}(15 \%) ; \mathrm{K}_{2} \mathrm{O}(15 \%) ; \mathrm{Ca}(1 \%)\right.\right.$;
Mg (1.4\%); S (2.7\%); Zn (0.5\%); B (0.05\%); Fe (0.5\%); Mn (0.05\%); Cu (0.5\%); Mo (0.02\%)].

\section{Traits measured}

At 90 days after pruning of formation, in the second year of cultivation, i.e., during the stage of full flowering of the West Indian cherry crop, the following parameters were evaluated: water saturation deficit (WSD), percentage of cell membrane damage (\%D) and gas exchanges, through stomatal conductance $(g s)$, transpiration $(E), \mathrm{CO}_{2}$ assimilation rate $(A)$, internal $\mathrm{CO}_{2}$ concentration $(\mathrm{Ci})$, instantaneous water use efficiency (WUEi) and instantaneous carboxylation efficiency

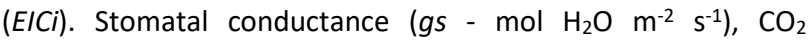
assimilation rate $(A)\left(\mu \mathrm{mol} \mathrm{H}_{2} \mathrm{O} \mathrm{m}^{-2} \mathrm{~s}^{-1}\right)$, transpiration $(E)$ ( $\mathrm{mmol}$ $\left.\mathrm{H}_{2} \mathrm{O} \mathrm{m}^{-2} \mathrm{~s}^{-1}\right)$ and internal $\mathrm{CO}_{2}$ concentration $(C i)\left(\mu \mathrm{mol} \mathrm{H}_{2} \mathrm{O} \mathrm{m}^{-2}\right.$ $\mathrm{s}^{-1}$ ) were measured at the height of the middle third of the crown, using a portable infrared gas analyser (IRGA - LCPro+ Portable Photosynthesis System $\left.{ }^{\circ}\right)$. After data collection, instantaneous water use efficiency (WUEi) (A/E) [ $\left(\mu \mathrm{mol} \mathrm{m} \mathrm{m}^{-2} \mathrm{~s}^{-1}\right)$ (mmol $\mathrm{H}_{2} \mathrm{O} \quad \mathrm{m}^{-2} \mathrm{~s}^{-1}$ ) ${ }^{-1}$ ] and instantaneous carboxylation efficiency $(E I C i)(\mathrm{A} / \mathrm{Ci})\left[\left(\mu \mathrm{mol} \mathrm{m} \mathrm{m}^{-2} \mathrm{~s}^{-1}\right)\left(\mu \mathrm{mol} \mathrm{mol} \mathrm{m}^{-1}\right)^{-1}\right]$ were quantified. At the same time, the percentage of cell membrane damage was determined following the methodology of ScottiCampos et al. (2013), according to Eq. 1:

$\% \mathrm{D}=\frac{\mathrm{ECi}}{\mathrm{ECf}} \times 100$

Where: $\% \mathrm{D}=$ percentage of cell membrane damage (\%); $\mathrm{ECi}=$ initial electrical conductivity $\left(\mathrm{dS} \mathrm{m}^{-1}\right) ; \mathrm{ECf}=$ final electrical conductivity ( $\mathrm{dS} \mathrm{m}^{-1}$ );

Leaf water saturation deficit was determined following the methodology described by Taiz \& Zeiger (2013), according to Eq. 2:

WSD $=\frac{\text { TW-FW }}{\text { TW-DW }} \times 100$

Where: WSD = water saturation deficit (\%); $F W=$ fresh weight of leaf (g); TW = turgid weight of leaf (g); DW = dry weight of leaf $(\mathrm{g})$.

\section{Statistical analysis}

The data obtained in the experiment were subjected to analysis of variance by $F$ test and when significant, means comparison test (Tukey at 0.05 probability level) was applied to the water salinity levels and regression analysis was applied to the $\mathrm{N}$ doses. When the interaction between factors (SL X ND) was significant, a follow-up analysis was carried out for saline levels with respect to $\mathrm{N}$ doses, using the statistical program SISVAR-ESAL (Ferreira, 2011).

\section{Conclusions}

Irrigation with $4.5 \mathrm{dS} \mathrm{m}^{-1}$ electrical conductivity water resulted in a reduction in stomatal conductance, transpiration, $\mathrm{CO}_{2}$ assimilation rate and instantaneous carboxylation efficiency, but increased cell damage percentage and internal $\mathrm{CO}_{2}$ concentration in West Indian cherry plants. Inhibition of $\mathrm{CO}_{2}$ assimilation rate in West Indian cherry plants is related to nonstomatal effects. Irrigation with $4.5 \mathrm{dS} \mathrm{m}^{-1}$ water associated with the highest $\mathrm{N}$ dose intensifies leaf water saturation deficit in West Indian cherry. Nitrogen doses did not mitigate the 
effects of the salt stress on water saturation deficit, cell damage and gas exchanges in West Indian cherry plants in the post-grafting stage. BRS Jaburu West Indian cherry is sensitive to $4.5 \mathrm{dS} \mathrm{m}^{-1}$ water salinity.

\section{Acknowledgements}

To the National Program of Post-Doctorate (PNPD/CAPES/UFCG), for granting the scholarship to the first author and to the National Institute of Science and Technology in Salinity - INCTSal, for funding the project.

\section{References}

Amorim AF, Gomes Filho E, Bezerra MA, Prisco JT, Lacerda CF (2010) Respostas fisiológicas de plantas adultas de cajueiro anão precoce à salinidade. Rev Ciênc Agron. 41:113-121.

Barhoumi Z, Atia A, Rabhi M, Djeball W, Abdelly C, Smaoui A (2010) Nitrogen and $\mathrm{NaCl}$ salinity effects on the growth and nutrient acquisition of the grasses Aeluropus littoralis, Catapodium rigidum, and Brachypodium distachyum. J Plant Nutr Soil Sc. 173:149-157.

Benzarti M, Rejeb KB, Messedi D, MNA AB, Hessini K, Ksontini M, Abdelly C, Debez A (2014) Effect of high salinity on Atriplex portulacoides: Growth, leaf water relations and solute accumulation in relation with osmotic adjustment. S Afr J Bot. 95:70-77.

Bosco MRO, Oliveira AB, Hernandez FFF, Lacerda CF (2009) Efeito do $\mathrm{NaCl}$ sobre o crescimento, fotossíntese e relações hídricas de plantas de berinjela. Rev Ceres 56:296-302.

Cantarella H. Nitrogênio. In: Novais R.F.; Alvarez VVH, Barros NF, Fontes RLF, Cantarutti RB, Neves JCL (2007). eds. Fertilidade do solo. Viçosa, MG, Sociedade Brasileira de Ciência do Solo. p.375470.

Cavalcanti FJ de A (Coord.) (2008) Recomendações de adubação para o Estado de Pernambuco: 2a aproximação. 2. ed. rev. Recife: IPA. 212 p.

Chaves LHG, Gheyi HR, Ribeiro S (2011) Consumo de água e eficiência do uso para cultivar de mamona Paraguaçu submetida à fertilização nitrogenada. Rev Eng Amb. 8:126-133.

Dembitsky V, Poovarodom S, Leontowicz H, Leontowicz $M$, Vearasilp S, Trakhtenberg S, Gorinstein, S (2011) The multiple nutrition properties of some exotic fruits: Biological activity and active metabolites. Food Res Int. 44:1671-1701.

Deuner C, Maia M de S, Deuner S, Almeida A da S, Meneghello GE (2011) Viabilidade e atividade antioxidante de sementes de genótipos de feijão-miúdo submetidos ao estresse salino. Rev Bras Sementes 33:711-720.

Donagema GK, Campos DVB de, Calderano SB, Teixeira WG, Viana JHM (Org.) (2011) Manual de métodos de análise de solo. 2. ed. Rio de Janeiro, RJ: Embrapa Solos. 230 p.

Epstein E, Bloom AJ (2006) Nutrição mineral de plantas: Princípios e perspectivas. 2. ed. Trad. Londrina: Editora Planta. 392p.

Ferreira DF (2011) Sisvar: A computer statistical analysis system. Ciênc Agrotec. 35:1039-1042.

Freire JLO, Dias TJ, Cavalcante LF, Fernandes, PD, Lima Neto AJ (2014) Rendimento quântico e trocas gasosas em maracujazeiro amarelo sob salinidade hídrica, biofertilização e cobertura morta. Rev Ciênc Agron. 45:82-91.

Habermann G, Machado EC, Rodrigues JD, Medina CL (2003) $\mathrm{CO}_{2}$ assimilation, photosynthetic light response curves, and water relations of 'Pêra' sweet orange plants infected with Xylella fastidious. Braz J Plant Physiol. 15:79-87.

Lima GS de, Nobre RG, Gheyi HR, Soares LA dos A, Silva AO da (2014) Crescimento e componentes de produção da mamoneira sob estresse salino e adubação nitrogenada. Eng Agríc. 34:854866.

Lúcio W da S, Lacerda CF de, Mendes Filho PF, Hernandez FFF, Neves ALR, Gomes-Filho E (2013) Crescimento e respostas fisiológicas do meloeiro inoculado com fungos micorrízicos arbusculares sob estresse salino. Semina: Ci Agrárias. 34:15871602.

Mendes BS da S, Willadino L, Cunha PC da, Oliveira Filho RA de, Câmara TR (2011) Mecanismo fisiológicos e bioquímicos do abacaxi ornamental sob estresse salino. Rev Caatinga 24:71-77.

Neves ALR, Lacerda CF, Guimarães FVA, Hernandez FFF, Silva FB, Prisco JT, Gheyi HR (2009) Acumulação de biomassa e extração de nutrientes por plantas de feijão de corda irrigadas com água salina em diferentes estádios de desenvolvimento. Ciênc Rural. 39:758-765.

Neves ALR, Lacerda CF de, Teixeira A dos S, Costa CAG, Gheyi HR (2010) Monitoring soil coverage and yield of cowpea furrow irrigated with saline water. Rev Ciênc Agron. 41:59-66.

Oliveira FA de, Oliveira FRA de, Campos M de S, Oliveira MKT de, Medeiros JF de, Silva OM dos P (2010) Interação entre salinidade e fontes de nitrogênio no desenvolvimento inicial da cultura do girassol. Rev Bras Cienc Agrar. 5:479-484.

Richards LA (1954) Diagnosis and improvement of saline and alkali soils. Washington: U.S, Department of Agriculture. 160p. Handbook 60.

Sá FV da S, Gheyi HR, Lima GS de, Paiva EP de, Fernandes PD, Moreira RCL, Silva L de A, Ferreira Neto M (2017) Water relations and gas exchanges of West Indian cherry under salt stress and nitrogen and phosphorus doses. J Agric Sci. 9:168177.

Scotti-Campos P, Pham-Thi, AT, Semedo, JN, Pais IP, Ramalho JC, Matos MC (2013) Physiological responses and membrane integrity in three Vigna genotypes with contrasting drought tolerance. Emir J Food Agric. 25:1002-1013.

Silva ARA da, Bezerra FML, Lacerda CF de, Pereira Filho V, Freitas CAS de (2013) Trocas gasosas em plantas de girassol submetidas à deficiência hídrica em diferentes estádios fenológicos. Rev Ciênc Agron. 44:86-93.

Silva EC, Nogueira RJMC, Araújo FP, Melo NF, Azevedo Neto AD (2008) Physiological responses to salt stress in young umbu plants. Environ Exp Bot. 63:147-157.

Silva LEN, Ferreira-Silva SL, Fontenele A de V, Ribeiro RV, Viégas RA, Silveira JA (2010) Photosynthetic changes and protective mechanisms against oxidative damage subjected to isolated and combined drought and heat stresses in Jatropha curcas plants. J Plant Physiol. 167:1157-1164.

Sousa JRM de, Gheyi HR, Brito MEB, Silva F de AFD da, Lima GS de (2017) Dano na membrana celular e pigmentos clorofilianos de citros sob águas salinas e adubação nitrogenada. Irriga 22:353368.

Sousa JRM de, Gheyi HR, Brito MEB, Xavier DA, Furtado G de F (2016) Impact of saline conditions and nitrogen fertilization on citrus production and gas exchanges. Rev Caatinga. 29:415-424.

Syvertsen, JP, Garcia-Sanchez F (2014) Multiple abiotic stresses occurring with salinity stress in citrus. Environ Exp Bot. 103:128137.

Taiz L, Zeiger E (2013) Fisiologia vegetal. 5.ed. Porto Alegre: Artmed. 918 p. 